\title{
PENYAKIT AKIBAT KERJA PADA PERAWAT DI RUANGAN ICU
}

\author{
Novrial Ahmad Hanif / ahmadnovrial15@gmail.com
}

\begin{abstract}
ABSTRAK
Pendahuluan: Keselamatan dan kesehatan kerja adalah kegiatan yang dirancang untuk menjamin keselamatan dan kesehatan di tempat kerja. Perawat berisiko terhadap kecelakaan dan penyakit akibat pekerjaan. Tujuan penelitian ini menganalisis pengaruh faktor predisposing, enabling, reinforcing dan core-care terhadap keselamatan dan kesehatan kerja pada perawat dalam penanganan pasienKata kunci: perencanaan, perencanaan keperawatan, Keperawatan di IGD.

Key Word : K3, Perawat, Perilaku, Keperawatan.

PENDAHULUAN

Perawat adalah tenaga kesehatan yang paling besar jumlahnya dan paling lama kontak dengan pasien, sehingga sangat berisiko dengan pekerjaannya, namun banyak perawat tidak menyadari terhadap risiko yang mengancam dirinya, melupakan keselamatan dan kesehatan kerja (K3).

Data WHO (2004): Dari 35 juta pekerja kesehatan bahwa 3 juta terpajan patogen darah (2 juta terpajan virus $\mathrm{HBV}$, 0.9 juta terpajan virus HBC dan 170.000 terpajan virus HIV/ AIDS). Probabilitas penularan HIV setelah luka tusuk jarum suntik yang terkontaminasi HIV 4: 1000. Risiko penularan HBV setelah luka tusuk jarum suntik yang terkontaminasi HBV 27-37: 100. Penelitian terhadap perawat perinatologi di RSUD Tugurejo Semarang, dalam satu tahun terakhir perawat mengalami kecelakaan kerja (tertusuk jarum) tertinggi 14 kali (Kurnia, 2013). Perawat dan pekarya kesehatan di RSI Malang, $100 \%$ tidak menggunakan handscoen saat mengambil sampel dahak, dan $90 \%$ tidak menggunakan sarung

tangan (handscoen) saat memasang infuse (Heny, 2005).

Penyakit Akibat Kerja (PAK) dan Kecelakaan Kerja (KK) pada petugas kesehatan dan non kesehatan di Indonesia belum terekam dengan baik, data kecelakaan di Rumah Sakit belum ada laporannya. Hasil survei Nopember 2014, dalam rentang tahun 2009 sampai tahun 2011, terdapat 2 orang perawat di Ruangan Interna menderita penyakit Hepatitis, diduga tertular dari pasien, kemudian dilanjutkan dengan survei pada bulan Januari 2015 di Ruang ICU dan Interna, pada 10 perawat hasilnya pencapaian ratarata keselamatan dan kesehatan kerja perawat di Rumah Sakit Benyamin Guluh Kab. Kolaka adalah 56\%, yang artinya K3RS belum optimal (Standar Kemenkes MFK dan PPI 100\%).

Penelitian tentang K3RS sudah banyak dilakukan namun analisis K3RS pada perawat dalam penanganan pasien dengan pendekatan teori precede-proceed dan teori model core, care dan cure belum pernah dilakukan, sehingga dengan pengembangan ini diharapkan keperawatan lebih berkembang lebih maju
\end{abstract}


dalam kaitannya keselamatan perawat dan keselamatan pasien.

\section{TUJUAN}

Tujuan penelitian ini adalah untuk memperoleh informasi atau gambaran yang nyata tentang pelaksanaan studi kasus pasien di ICU

\section{BAHAN DAN METODE}

Desain penelitian ini adalah cross sectional yaitu desain penelitian analitik yang bertujuan mengetahui hubungan antar variabel independen dan variabel dependen. Dilaksanakan di RSBG Kab. Kolaka dari tanggal 12 Maret sampai dengan 12 April 2015. Populasi penelitian ini adalah seluruh perawat yang bekerja di RSBG Kabupaten. Kolaka. Penarikan sampel secara proposional random sampling dengan kriteria inklusi dan inklusi. Sampel terdiri dari 100 orang perawat. Pengukuran variabel independen dan dependen faktor predisposing (pengetahuan, sikap kepercayaan dan nilai), faktor reinforcing (petugas yang menjadi contoh K3RS), faktor enabling (fasilitas dan aturan) serta faktor corecare (hubungan interpersonal dan kepedulian diukur dengan menggunakan kuesioner. Variabel dependen yaitu K3RS (mencuci tangan, memakai handscoen, memakai masker, memakai apron, pengelolaan benda tajam dan pengelolaan lingkungan) diukur dengan kuesioner. Data dianalisis secara multivariat dengan menggunakan program PLS-Smart versi 3.0 untuk mengetahui pengaruh faktor predisposing, reinforcing, enabling dan corecare terhadap keselamatan dan kesehatan kerja pada perawat. dan menguji hipotesis.

HASIL
Uji validitas konstruk dengan indikator formatif dapat dilakukan dengan melihat tstatistics pada outer weight, di mana suatu indikator dikatakan valid jika memiliki nilai tsattistics > t-tabel, dengan alfa 5\% (two-tailed) diketahui nilai t-tabel adalah 1,96. Berikut adalah nilai t-statistics dari masing-masing indikator pada variabel penelitian. Hasil nilai outer weigh menunjukkan bahwa ada satu indikator yaitu kepedulian yang memiliki nilai tstatistics $<1,96$ sehingga konstruk care tidak lulus uji validitas konstruk, namun indikator ini merupakan indikator refleksif, walaupun tidak memenuhi uji validitas konstruk (yaitu terdapat salah satu atau lebih indikator yang tidak signifikan) indikator tersebut tetap dapat dilanjutkan dalam model struktural, karena perubahan indikator ref lektif tidak menyebabkan perubahan konstruk, serta menghilangkan satu indikator tidak akan mengubah makna konstruk (Ghozali, 2012).

\section{PEMBAHASAN}

Faktor predisposing (pencetus) (pengetahuan, sikap. Kepercayaan dan nilai) pada perawat terhadap K3RS yaitu memiliki hubungan yang sangat berpengaruh terhadap keselamatan dan kesehatan kerja pada perawat dalam penanganan pasien di RSBG Kab. Kolaka, bahkan faktor ini bila dilihat dari nilainya merupakan faktor yang paling dominan mempengaruhi K3RS, berdasarkan hasil uji PLS nilai dari seluruh komponen berkorelasi sangat baik, sedangkan nilai tertinggi pada indikatornya adalah komponen kepercayaan, artinya bahwa kepercayaan memiliki nilai yang sangat baik dan memiliki pengaruh yang sangat baik terhadap perilaku seseorang, sedangkan nilai untuk pengetahuan adalah 
yang paling rendah. Kepercayaan merupakan keyakinan terhadap sesuatu kepercayaan bersifat abstrak, sebagai contoh seseorang yang memiliki agama yaitu mereka percaya dan yakin bahwa suatu saat akan ada yang disebut kiamat, walaupun belum pernah melihat dan merasakan mereka yakin bahwa hal itu ada, maka dengan demikian mereka berusaha untuk berbuat yang terbaik untuk menghadapi hal tersebut. Kepercayaan inilah yang mendasari perilaku perawat bahwa K3 sangat penting dan sangat berarti untuk dirinya, sehingga mereka berperilaku yang baik terhadap pelaksanaan K3RS. Faktor reinforcing (pendorong) (petugas yang menjadi contoh) pada perawat terhadap K3RSHasil uji statistik nilai faktor reinforcing (petugas yang menjadi contoh) ini tidak berpengaruh terhadap keselamatan dan kesehatan kerja pada perawat dalam penanganan pasien di RSBG Kabupaten Kolaka, dengan nilai t-hitung 1,098 < ttabel 1,96 artinya secara kesahihan dan keandalan instrument sebagai alat ukur sudah memenuhi syarat namun sebagai veriabel yang mempengaruhi perilaku keselamatan dan kesehatan kerja tidak berpengaruh, hal ini mungkin terjadi karena petugas yang bertanggung jawab kurang melaksanakan tugas K3 sebagai akibat tugas rangkap, maka bila telah dilaksanakan dengan kesadaran sendiri faktor pendorong kurang berarti, sehingga tidak berpengaruh terhadap keselamatan dan kesehatan kerja. Perawat di RSBG Kolaka menganggap bahwa petugas K3 yang bekerja saat ini tidak memiliki kontribusi terhadap keselamatan dan kesehatan kerja. Faktor enabling (fasilitas keamanan dan keselamatan, hukum/aturan) pada perawat terhadap K3RS. Faktor enabling berpengaruh terhadap $\mathrm{K} 3$ pada perawat dalam penanganan pasien di RSBG kab. Kolaka nilai t-hitung 2,388 > t -tabel 1,96, sebagai faktor yang memungkinkan suatu proses perilaku, maka faktor ini memiliki kedudukan yang cukup strategis di mana perubahan tidak dapat terjadi bila faktor ini tidak disiapkan fasilitas pendukungnya. Nilai yang paling tinggi pada faktor enabling berada pada komponen hukum/aturan karena pada prinsipnya perilaku seseorang dipengaruhi oleh aturan yang ada di lingkungannya, sebagai contoh seseorang yang bekerja sebagai prajurit maka ia harus menaati peraturan dan disiplin terhadap aturan bila tidak maka ia akan terkena hukuman. Kebiasaan dalam menaati aturan ini menjadi kebiasaan yang baik sehingga ia tidak akan melanggar aturan karena kebiasaan disiplin dan sanksi dari aturan tersebut. Factor core and care. Faktor core, and care (hubungan interpersonal dan kepedulian) berpengaruh terhadap keselamatan dan kesehatan kerja pada perawat dalam penanganan pasien di RSBG Kab. Kolaka, nilai t-hitung 1,963 > t-tabel 1,96. Core, and care, namun pada hasil outer wight nilai yang paling tinggi adalah core, sedangkan care tidak signifikan, hal ini mungkin dipengaruhi oleh indikator care yang kurang variasi dalam pertanyaan dalam instrument indikator kepedulian tidak mempunyai nilai yang bermakna.

\section{SIMPULAN DAN SARAN}

Simpulan Faktor predisposing merupakan faktor dominan yang menentukan keselamatan dan kesehatan kerja pada perawat, sedangkan kepercayaan merupakan indikator yang sangat dominan berpengaruh. pada faktor predisposisi ini dibanding yang lain. Faktor tidak mempengaruhi keselamatan dan kesehatan 
kerja pada. Faktor enabling mempengaruhi keselamatan dan kesehatan kerja pada perawat. faktor core-care kurang dominan mempengaruhi keselamatan dan kesehatan kerja pada perawat dalam penanganan pasien di RSBG Kab. Kolaka, di mana pada indikator care (peduli) tidak bermakna dalam kontruk core-care. Rekomendasi pengembangan teori precede-proceed dan core, care, and cure terhadap K3RS, yang dapat dilanjutkan melibatkan faktor predisposing, enabling, core and care. Saran Koordinator K3RS dan pengendalian infeksi yang telah ditunjuk oleh Direktur RSBG Kab. Kolaka melaksanakan tugas K3RS dengan baik agar program ini dapat meningkatkan mutu, kualitas layanan dan akreditasi rumah sakit, dan perawat diharapkan tetap menjaga dan meningkatkan pengetahuan, sikap, kepercayaan, nilai, hubungan interpersonal, serta tetap peduli pada keselamatan dan kesehatan kerja, untuk menjaga dan meningkatkan keselamatan dan kesehatan diri agar tetap sehat, selamat dan produktif. Peneliti selanjutnya dapat melanjutkan penelitian ini dengan model keperawatan safety yaitu safety perawat dan safety pasien sebagai pengembangan ilmu keperawatan.

\section{PENUTUP}

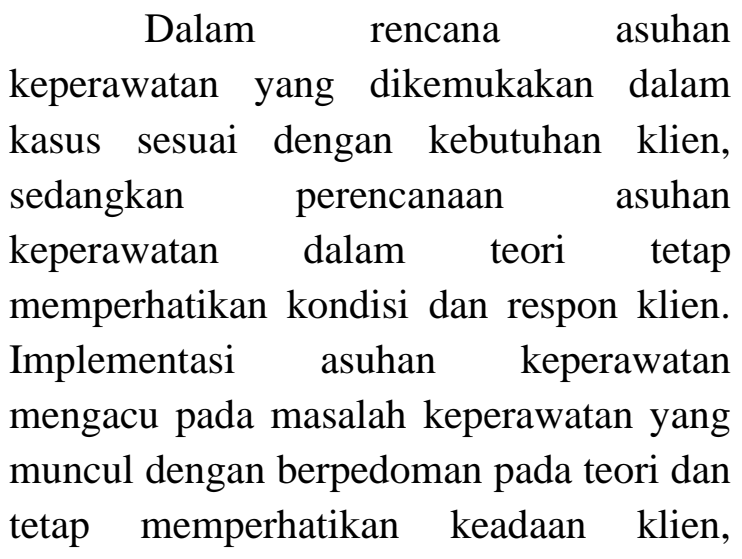

respon klien serta fasilitas yang ada dan kebijakan dari rumah sakit.

\section{DAFTAR PUSTAKA}

1. Alligod, T., 2010. Nursing Theorists and Their Work. (Edisi 7). USA: Mosby. Inc, Elsevier.

2. DEPKES RI, 2009. Standar Kesehatan dan Keselamatan di Rumah Sakit. Dirjend Bina Kesehatan Masyarakat. Jakarta.

3. Frestianiasari \& Fenti., 2008. Pengetahuan dan Sikap Perawat tentang Pelaksanaan K3-RS di Bapelkes (RSUD) Genteng Banyuwangi. Jurnal Unair ADLN Perpustakaan Unair.

4. Ghozali I, Latan H., 2012. Partial Least Squares Konsep, Metode dan Aplikasi Badan Penerbit Universitas Diponegoro. Semarang.

5. Green, L., 2000. Health Promotion Planning and Educational Environment Approach, Second Edition Kesehatan dan Keselamatan Kerja, Mayfied Publising Company. Montain View, USA.

6. Nursalam. 2013. Metodologi Penelitian Ilmu Keperawatan: Pendekatan Praktis. Edisi 3. Salemba Medika. Jakarta.

7. Nursalam. 2014. Manajemen Keperawatan, Aplikasi dalam Praktik Keperawatan Profesional. Edisi 4. Salemba Medika. Jakarta.

8. Permana, L,W, Adisasmito, W., 2004. Analisis Pelaksanaan Tugas dan Fungsi Panitia 
Pengendalian

Infeksi

Nosokomial

Pelayanan

Kesehatan St Carolus Jakarta.

Jurnal K3 02 Juni 2005.

9. Simamora, R. H. (2017). A strengthening of role of health cadres in BTA-Positive Tuberculosis (TB) case invention through education with module development and video approaches in Medan Padang bulanComunity Health Center, North Sumatera Indonesia. International

Journal of Applied Engineering Research, 12(20), 1002610035.

10. Simamora, R. H., \&Saragih, E. (2019).

Penyuluhankesehatanterhadap masyarakat:

Perawatanpenderitaasamuratde ngan media audiovisual. JPPM (JurnalPendidikandanPemberd ayaanMasyarakat), 6(1), 24-31.

11. Sholihah, H,H. 2005, Pelaksanaan Universal Precautions oleh Perawat dan Pekarya Kesehatan (Studi Kasus di Rumah Sakit Islam Malang Unisma) Jurnal Pusat Penelitian Pengembangan Teknologi Surabaya.

12. Takuatman DKK,. (2015). ANALISIS KESELAMATAN DAN KESEHATAN KERJA PERAWAT DALAM PENANGANAN PASIEN DI RUMAH SAKIT BENYAMIN GULUH KABUPATEN KOLAKA (Analysis of Nurse's Occupational Health in Managing Patients in Benyamin Guluh Hospital
Kolaka Regency) . Jurnal Ners Vol. 10 No. 2 Oktober 2015: 343-347 